\title{
Indigenous Santal People Sense and Etiology Regarding Black Fever IIIness
}

\author{
Md. Yeamin Ali ${ }^{1}$, Md. Redwanur Rahman ${ }^{1}$, Akib Javed ${ }^{2}$, Arook Toppo ${ }^{1}$, Mst. Rupali Akhtar ${ }^{3}$ \\ ${ }^{1}$ Institute of Environmental Science, University of Rajshahi, Rajshahi, Bangladesh \\ ${ }^{2}$ Department of Geography and Environment Studies, University of Rajshahi, Rajshahi, Bangladesh \\ ${ }^{3}$ Department of Political Science, University of Rajshahi, Rajshahi, Bangladesh
}

Email address:

yeaminiesru@gmail.com (Md. Y. Ali),redwan_rahman@lycos.com (Md. R. Rahman), akib.jr@gmail.com (A. Javed), arook_toppo.rro@caritasbd.org (A. Toppo), akhtarrupali@gmail.com (Mst. R. Akhtar)

\section{To cite this article:}

Md. Yeamin Ali, Md. Redwanur Rahman, Akib Javed, Arook Toppo, Mst. Rupali Akhtar. Indigenous Santal People Sense and Etiology Regarding Black Fever Illness. American Journal of Health Research. Vol. 4, No. 5, 2016, pp. 143-150. doi: 10.11648/j.ajhr.20160405.16

Received: August 8, 2016; Accepted: August 19, 2016; Published: October 9, 2016

\begin{abstract}
The study aim is to know indigenous people perception, diagnosis and etiology about black fever. The perception of black fever differs to them. To them, black fever means curse of God, black power and black magic. $70 \%$ patients know about black fever through NGO or medical test. Indigenous Santal people said about different physical characteristics of black fever. Those are angry, cold felling and avoiding rice, headache, lack of blood, birth of dead children, belly become big and stop menstruation, loss of weight and strength etc. People's knowledge about black fever, long time to recognize black fever, belief in supernatural power, belief it is touchable and fear about stigma effect on treatment of black fever patient. 78\% patients believe their poor knowledge regarding black fever affect treatment process. After taking treatment from NGO or medical center $45 \%$ people didn't face any side effect and rest of them face side effect.
\end{abstract}

Keywords: Indigenous, Santal People, Sense, Etiology, Black Fever, Bangladesh

\section{Introduction}

Black fever or leishmaniasis is one of major tropical diseases research by Word Health Organigation (WHO) [1, 2]. Worldwide 20,000 - 30,000 people die and 186 million people are at risk of Visceral Leishmaniasis VL [3]. Humans are considered as only source of infection for the sandflies vector [4]. 90\% of black fever occurs in Bangladesh, Brazil, Ethiopia, India, Nepal, South Sudan and Sudan [5] where 300,000 new Visceral Leishmaniasis (VL) occur annually. That's why South Asia is considered as the highest Visceral Leishmaniasis (VL) prone region in the world [6].

In Bangladesh, black fever re-emerged sporadically in the decade of 1970s. It increases from 3,978 in 1993 to 9,379 in 2006. Last few years, the incident declined significantly and was reported only 1103 in 2013 [7]. Visceral Leishmaniasis (VL) reported cases are second highest in Bangladesh among Indian subcontinent [8]. Post Kala-azar Dermal Leishmaniasis (PKDL) burden within Indian subcontinent is highest in Bangladesh [9].
In northern Bangladesh, it has been highly prevalent among the ethnic minorities. In 2004, according to a local newspaper, around 500 ethnic people from three Santal villages were affected by black fever [10].

The causes of the illness influenced by their choice of health care options. The cultural elements of Santal people, such as, religious belief, socio-economic conditions, environmental condition and traditional practices have influenced their health seeking behaviors. The study aims to reveal the reasons behind of sporadically prevalence of black fever among the plain land indigenous Santal people. That's why it is important to know their health seeking behavior regarding black fever.

Black fever or leishmaniases or kala-azar are caused by 20 species of Leishmania and transmitted by less than 35 species of female sandflies [11, 12]. Visceral Leishmaniasis (VL) and Cutaneous Leishmaniasis (CL) are two types of leishmaniases diseases [13]. The syndromes of Visceral Leishmaniasis (VL) are fever, weight loss, splenomegaly, hepatomegaly, skin darkening and anemia [14]. 


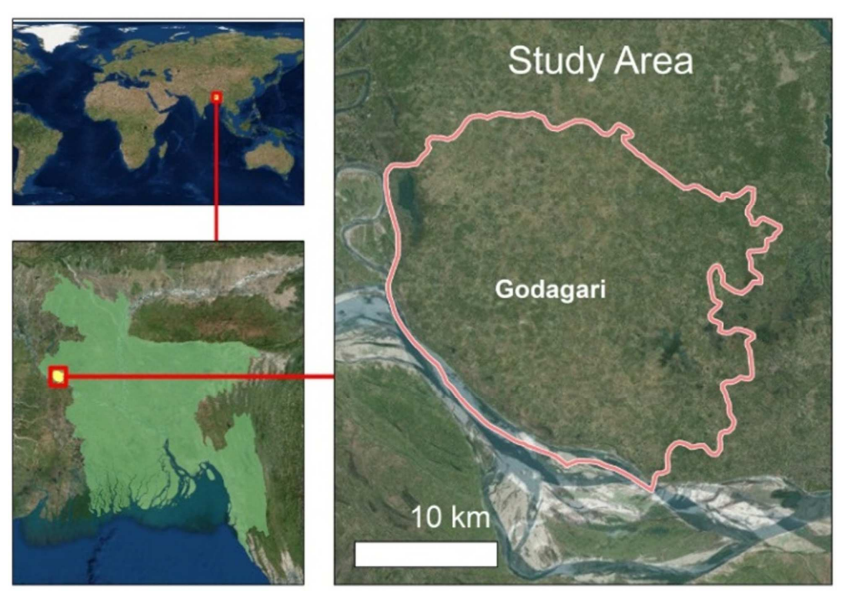

Figure 1. The study area.

The study also aim is to know the understanding of black fever to the ethnic Santal people, its causes of occurrence amongst them and their indigenous diagnosis system to examine the disease.

\section{Methodology}

The study is explorative and to some extent descriptive in nature that enforces to adopt mixed with qualitative and quantitative data as well as secondary and primary data. The primary data were collected from some structured questionnaires, interviews, focus group discussion and observations. The secondary data was collected from different sources. The questionnaire survey was conducted based on sampling which includes 100 respondents. The primary data was analyzed using various statistical software. Researcher used the purposive sampling. Because my research is related with black fever that's why Researcher selected black fevers Patient as my respondent. Researcher also used snowball sampling for the research. Sometimes, Researcher selected respondent by knowing another respondent. Who is attacked by black fever? So finally researcher used purposive sampling and snowball sampling for by research. In this study, researcher tried to understand indigenous Santal people sense and etiology regarding black fever.

\section{Study Area}

Rajshahi district, located in the north-west of the country, is one of the oldest and historically important areas of Bangladesh. An estimated population of Rajshahi District is 853,000 people (BBS 2012) [15] with total area of $96.69 \mathrm{~km}^{2}$ (37.33 sq. miles). It is lying beside northern banks of the river Padma. A quality treatment facility developed over decades in the city. Patients from surrounding district come to Rajshahi for quality health care service. But those indigenous people live in periphery did not get those facilities. Their perception and etiology regarding illness is the barrier of treatment.

Researcher worked with black fever patient perception and etiology among the indigenous people. Godagary Thana of Rajshahi district has been selected as study area due to high prevalence of black fever among the ethnic communities. A large number of black fever affected patient live in the Godagary Thana of Rajshahi district, an estimate number of black fever patient 500 (Sonali Sangbad, 2004) [10] which is one of the highest black fever prevalence area in Bangladesh. That why our research team select Godagary as study area.

Moist soil, caves, cervices in the mud-flood, coral stones used to construct parapet-wall etc. are responsible for sand fly breeding [16].

Our research team worked in the three villages of Godagary in the Rajshahi distinct.

\section{Results and Discussion}

In Rajshahi district, total 1300 black fever patient reported, from 1994 to 2004. But, in 2004, there was a major out brake of black fever in three indigenous Santal villages in Rajshahi district. 500 patients from 115 families reported got black fever that year [10].

\subsection{Ethnic Understanding of Black Fever}

Black fever is a kind of fever that exists for long time in the human body. The indigenous people call it black fever (kala-azar), because, the skin of the affected people turns black in color. Some of the respondent use this term, because, the influence of NGO persons and doctors. Some people believe it is a curse of god. Some people think, it is resulted from black magic or bad power. It attacks the people and wants to kill the people. It is secret killer and first time people didn't recognize it.

\subsubsection{Black Fever as Curse of God}

Indigenous people believe that, when people from a community engaged in sinful act or make more sexual violence, then, God sent black fever as a curse to them. It is a punishment for the people. In 2004 all most all the villager attacked by the black fever. In that year, two girls, went away from the community and married a Muslim man. The Santal people did not take any step about that. The practice of Santal community is, women must not marry other than Santal man. They think, it is against the law of their religion. Some people believe, this incident might anger God and the villager ended up affected by black fever because of that anger. In that particular year, the son of the chief (Moral) died. People believe, it might be a consequence of, the chief (Moral) didn't give any ruling against the marriage of the two girls.

They also believe, most of the people died because it was a curse of God. Additionally, medicine cannot able to cure them. Only if god forgives, then they will cure. In addition, they also believe, only those who seek forgiveness to god continuously, got cured. It is the forgiveness of God, that some black fever affected people did not die.

Researcher asked one respondent, how you explain that, even now some people are affecting by black fever. $\mathrm{He}$ replied, "three months ago a fourteen year children died because his father was a guilty person. He always drinks Haria (locally produced liquor). He fights with other people, 
makes sexual violence and he speaks in foul languages. So, God punish that person by taking away his son. The man got sick too, but, got cured. He also said that, the man tried all possible treatment he can afford, but, couldn't cure his children.

\subsubsection{Black Fever as Bad Power}

Some of the respondents believe, a bad power is responsible for black fever. When bad power attacked the community, then it is called black fever. Bamon (a short size devil, lived in palm tree, believed by Santal community) have the bad power. It looks like a small man. They stay in the $\mathrm{Tal} / \mathrm{palm}$ Tree. In the Santal society or northern belt of Bangladesh have common story about the Bamon. When some person in middle night come through under the tal $/ \mathrm{palm}$ tree then Bamon get down from the tree and hit on the human chest and the human became sense less. There is another common talk is that Bamon like to eat death person human liver.

When power of Bamon attacked the community it called black fever. And other most important thing is that black fever also attacked in the liver and some of the internal organ.

\subsubsection{Black Fever as Black Magic}

Some of the respondent said, that, black fever is caused by black magic. It comes from black magic. When someone practice magic to the other person that person attacked by the black fever. They want to damage the koliza (liver) by Black magic. The magician spells the magic for his anger to other person or sometime he does it for his/ her normal practice, researcher asked respondent that how you can have said those word. He told us, that, he was attacked by black fever. At first he did not understand it, his thing that it is normal fever. But gradually he just became weak. At that time, he just takes normal treatment form indigenous physician (kabiraj). Later, he took medicine from the quack but that medicine didn't work. Finally, he lay down in the bed. Then his father admits him in the medical hospital. From medical hospital he took a lot injection and other medicine but didn't cure. Doctor sends them back to house. That times his condition was so bad and his skin became black. Then suddenly a person came and said them to talk with shaman (ogza=witch). Then his father thing about it, and discuss about his condition with a shaman (ogza) from Natore. Later, shaman $(\operatorname{ogza})$ said that he attacked by black magic. Later, he said that they found a doll in your house. By that doll the magician practicing magic. Later, they found a doll in a corner of house under soil. In the chest of the doll have a hole and it cover with something black. He explains that he became black for that black color and the whole working in the chest and specially in the liver. Shaman (ogza) give him treatment and said them it is black magic and he became cure. So that why they said black fever is a black magic.

\subsubsection{Black Fever as Touchable}

Some of the villagers believe, black fever is touchable and it transmitted from another person. Some believe, it might come from nature and then it spread among the villager. Few people believe, the Indian cow, imported from Assam, might bring black fever virus with them. Because, these cow move a long way through different area. In that area, some may be affected with black fever. Some respondent believes these diseases come from foreign land.

Some of them said, may be it comes from dead body. They claim that, when we don't grave our dead bodies, and give it to police and they sent them to hospital. Later, hospital operates post mortem operation on the dead bodies and didn't give our dead man back. So, God send black fever as a punishment from dead body. So that, we bury our dead bodies and do not sent them for post mortem.

\subsubsection{Black Fever and Pig}

Some of the respondents said, it come from the pig. Pig always eats filthy and dusty things. The poison transmits from pig to human when people consume pig. For this reason, church forbids pig rearing in the Noabi Bottoli village. But, now a day, some people still rearing pig. Because, it is related with their traditional practices. The ethnic people still like to eat pig in their festival with Haria (locally produced liquor).

\subsubsection{Black Fever and Myth}

When researchers collect data, we found something interesting related to myth. For ethnic people, duck is an important animal. They belief that's duck is the first animal in the world. Duck give egg and from egg the world create. Some of our respondent said when people eat duck's liver in the winter season then there may be a possibility to attack by black fever. They also belief when dog cry in the night there is possibly to attack by black fever.

Table 1. Meaning of black fever to Santal people.

\begin{tabular}{ll}
\hline Meaning of black fever to the indigenous people & Percent (\%) \\
\hline Black fever curse of God & 44 \\
Black fever as bad power & 41 \\
Black fever as black magic & 5 \\
Other & 10 \\
\hline
\end{tabular}

Table 1 shows that, almost half of the Santal villager believes that, black fever is a curse and it comes from God. Another $41 \%$ people believe, it's a result of bad power. Some people believe it is coming from black magic. There are some other believe too.

\subsection{Local Indicator to Identify Black Fever}

Local people have their own understanding of sign to identify black fever. The most important indicator for them is, whoever got black fever likes to eat fried fish and fried rice (Chal vaja) and always try to avoid rice. One of the respondents, Rojina Murmu, aged 32 with her husband name is luis kislu, age 37 both live in the Nobai Bottole. They have two rooms in the house and have no boundary. Her brother's in law (brother of her husband) was a practicing indigenous 
physician (kobiraj). Her son Judo Kislu, student of class three, once, suddenly has started to avoid having rice. Similarly, he's showing interest in fried rice (chal vaza) and fried fish. By avoiding regular diet, which is rice, their son was becoming sick day by day. After 7 days later, she told her brother in law, the indigenous physician, about the condition of her son. He figures out these symptoms as an indicator of black fever patient. The indigenous physician (kobiraj) prescribes some treatment and within 20 days her son got cured. According to them, black fever Patients always show interest in fried foods.

\subsubsection{Angry, Cold Feeling and Avoiding Rice}

Another respondent was telling her story. She said, suddenly her husband starts behaving roughly with her. $\mathrm{He}$ used to become very angry within no time. He was maltreating their children too. He used to beat children and his wife. Her husband was avoiding rice. She requests her husband to eat but he refused. In one evening, he just goes to sleep with his blanket. Usually, he gossips with his neighbor in this time. In addition, he used to go to bed at night. Later, he asks for some fried rice. Later, she found him got fever. She took her to treat from quack. Later, during bathing, her husband found something hard, round abnormal thing in his belly. He also found his belly growing large. So, they try medicine from different place. One morning, he was feeling pain in the stomach and start blood vomiting. It continues for two days and finally he died.

\subsubsection{Headache, Lack of Blood and Birth of Death Children}

Another women respondent got black fever, but, she recovered. She was pregnant of eight months. During her pregnancy, she used to fell headache and was unable to having regular diet. Her mother in law thought, it happening normally, because of her pregnancy. Her headache continues for 5 days, in addition she got fever. Her husband brought medicine from pharmacy. She continues that medicine for 15 days but it didn't work. Suddenly, she felt severe pain. So much so, she got admitted to medical hospital. There she gave birth a dead child and in need of blood. Doctors made different test and identified her condition as black fever. Later, she gets proper treatment and cured.

\subsubsection{Belly Became Big and Stop Menstruation}

Researchers talked to a woman, whose sister died of black fever. The entire villager neglected them. Her sister belly became big and her menstruation stopped. His sister was unmarried and was an undergraduate student of Rajshahi College. The entire village people misunderstood her big belly with pregnancy. They accused her to be a fornicator. Everyone avoided them and often pass negative comment on her. Days passed and her sister became weak. Even she's unable to move. Later, some NGO worker found her and they admitted her to a hospital. Doctors found out, it was not pregnancy.

\subsubsection{Lose of Body Weight and Strength}

Losing weight and strength are signs of getting black fever.
Santal people noticed, those who got black fever, they don't like to work and they like to stay alone. One of our respondents' brother died of black fever. His brother was a day labor. He was a strong man and didn't used to miss his work. At the first stage of fever, he starts showing irregularity in his working place. Later, he was so weak and to work. He became thin too. His brother takes treatment from indigenous physician (Kabiraji). But it didn't cure. Later, he was madly shouting out, that, he cannot able breath. That's why he died.

Researchers found another woman name Lodia Murdi. She is 40, live in Rajshahi. Her husband died of black fever too. It was 6 year ago, one day, her husband told her that, he's not feeling ok. Firstly, it was only headache. In that evening he got fever. He thought it's a normal fever. It will be cure later. So, he continues his work with fever. After two weak later, he starts avoiding rice and he felt no test in his tongue. He took medicines from quack. He continues that medication for one and a half month. Later, he became very weak. His fever got high. He's got bed and felt pain in his belly. His spleen got fat. Later his body turns into black and eyes turns in to white. After few days he died.

Table 2. Physical characteristic of black fever.

\begin{tabular}{ll}
\hline Physical characteristic & Percent (\%) \\
\hline Angry, cold felling and avoiding rice & 42 \\
Headache, Lack of blood and Birth of death children & 12 \\
Belly became big and stop menstruation & 10 \\
Lose of Body weight and strength & 36 \\
\hline
\end{tabular}

We can see from the Table 2, most of the people of Santal villages identify black fever when a person avoiding rice, feeling cold and lose his temper with fever. Other $36 \%$ respondents identify black fever when someone loses body weight and strength. There are some other symptoms too. Those are headache, anemia, birth of dead children, belly enlargement, break of menstruation etc.

\subsubsection{Stages of Black Fever}

Different respondents said about different symptom about black fever. According to the respondent's perception we can divided the stages of black fever (kala-azar) into three phases. Those are primary phase, secondary phase and acute phases.

In the primary phase, the symptoms are people eat little rice, feel bad headache and got fever. They felt cold in the evening, lost tasted of food and lose temper. In the secondary stage, some signs are they became very weak, body temperature rise, spleen got bigger. In the last stage, loss of body weight, anemia, spleen felt like broken down, body turns in black in color and trouble in breathing are some symptoms. Finally, the patient got died. For female, some symptoms are stop of menstruation, give birth of dead child and belly enlargement etc. 
Table 3. Stages of black fever according to indigenous Santal people.

\begin{tabular}{|c|c|c|c|}
\hline Name of phases & Metaphor of the phases & Initial choice of treatments sector & Ritual practice of respective phases \\
\hline Primary & $\begin{array}{l}\text { The patient and his relative treated this } \\
\text { phase as normal and their respective with } \\
\text { the patient is usual }\end{array}$ & $\begin{array}{l}\text { Family is the main choice of treatment in } \\
\text { the phase. The popular sector is } \\
\text { dominantly practiced during this phase }\end{array}$ & $\begin{array}{l}\text { Patient has to obey the rule and regulation } \\
\text { prescribe by family, such as not to visit } \\
\text { outside the house always has to stay in the } \\
\text { room }\end{array}$ \\
\hline Secondary & $\begin{array}{l}\text { The patient and his relative treated this } \\
\text { stage as less serious. the old person and } \\
\text { children have prohibited meeting and } \\
\text { talking with patient }\end{array}$ & $\begin{array}{l}\text { The folk sector of treatment are greatly } \\
\text { prescribed by the society in this stage }\end{array}$ & $\begin{array}{l}\text { Patient has to stay in a single room. he } \\
\text { has fail to talk and meet with his } \\
\text { respective friends and person }\end{array}$ \\
\hline Finally & $\begin{array}{l}\text { The patient and his relative treated this } \\
\text { phase as serious. without the mother } \\
\text { respective old women's of patient all } \\
\text { people are forbidden to talk and meeting } \\
\text { with patient }\end{array}$ & $\begin{array}{l}\text { Folk and professional both sector of } \\
\text { treatments are practice during this stage }\end{array}$ & $\begin{array}{l}\text { The patient has to eat or drink by a } \\
\text { separate plate or glass. He cannot neither } \\
\text { talk nor meet with other. }\end{array}$ \\
\hline
\end{tabular}

\subsection{Santal People's Practice and Black Fever}

There are several reasons responsible for ethnic Santal people to get black fever. Their life style and culture practice are significantly responsible for causing black fever. Their housing patterns, behavior towards domestic animal are also causing to grow sand fly. Villagers said that, one people from icddr'b starts catching sand fly and they get 1800 sand fly from one house only.

\subsubsection{Housing Pattern and Traditional Practices}

Their house pattern is a major responsible factor. Santal people don't keep any window in their houses, because their ancestor used to do so. They keep their room dark and keep everything in the living room. So, sand fly and other insect can easily bite them.

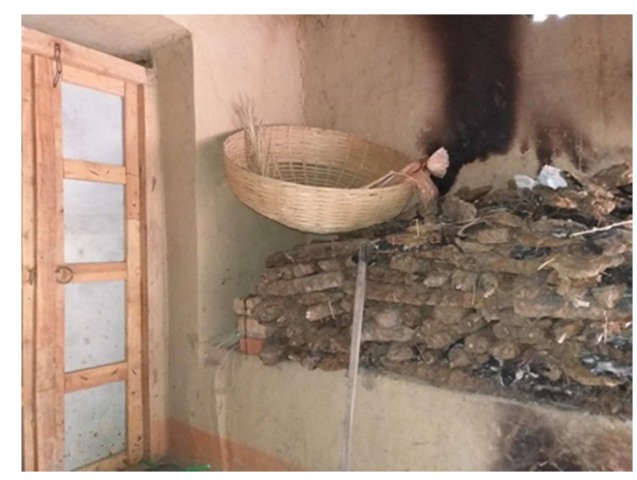

Figure 2. Cow dung made fuel kept inside the room.

According to one respondent, if they discontinue the practices, which inherit form their ancestor, their every other practices will change eventually. That will result the loss of land, loss of big tress, where they believe God stays. In addition, God can stay in darkness of their house. That's why they don't keep window in their house.

\subsubsection{Lack of Space, Poverty and Jungle}

Some of the Respondent claim that, it because lack of land they keep everything in a single room. Their housing condition is related to their cultural practice. They also argue that, they don't have enough time to organize their houses.
Both male and female works are day labor. So, no one left home to clean their house. One can found dust around the house. Location of their house is also important factor. They build their house next to jungle. That's make a safe place for sand fly.

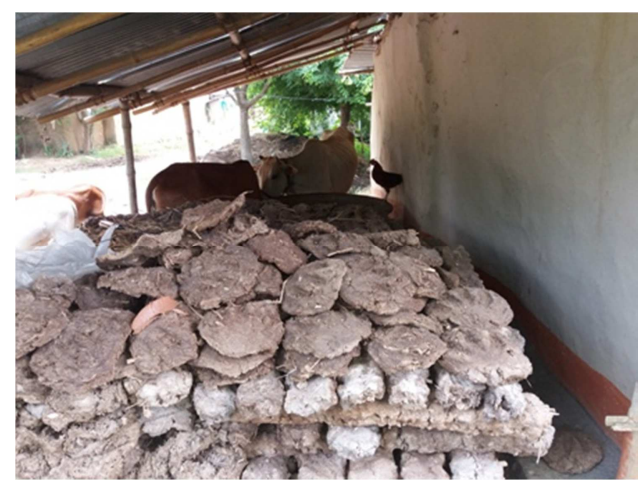

Figure 3. House surroundings are messy.

\subsubsection{Soil Wall Hole and Broken in the Wall}

The materials they use to build residence is also having a positive impact on growing sand fly. They use muddy wall in their houses. There are many holes and broken spots found in the wall. Sand fly could stay there and bite the household people. Caritas (an NGO) provide them net, but, they did not use them. They used to sleep openly and using net hampering their sleep. Net makes them boredom too. So, sand fly can easily bite them.

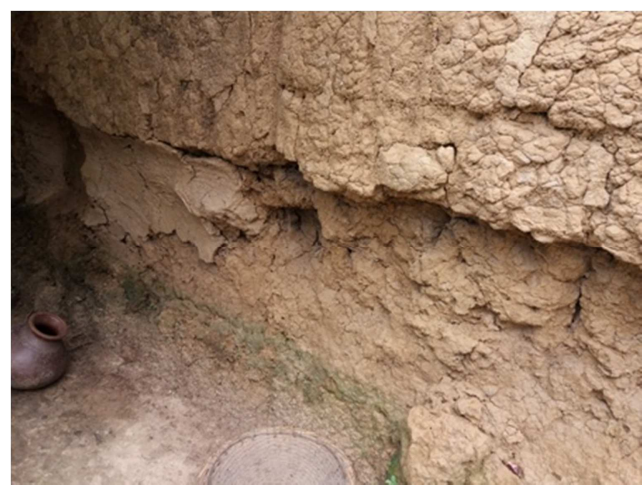

Figure 4. Broken wall with hole. 


\subsubsection{Sleeping without Net and Malnutrition}

One Santal man said, he never uses net since his birth. He also said, changing his habit regarding use of net is impossible. Furthermore, they consider it as adopting else religious symbol. Not using net is like a strong cultural practice to them, which they cannot abandon.
Santal people are working people, but they're having malnutrition problem. It leads them to physical weakness and their immune system is weak too. So, they are prone to diseases too.

Table 4. Causes of black fever.

\begin{tabular}{|c|c|c|c|c|}
\hline \multirow{2}{*}{$\begin{array}{l}\text { Degree of impact Attacking } \\
\text { by Black fever }\end{array}$} & \multicolumn{4}{|c|}{ Causes for attacking by black fever } \\
\hline & $\begin{array}{l}\text { House Pattern and } \\
\text { traditional practice }\end{array}$ & $\begin{array}{l}\text { Lack of space, Poverty } \\
\text { and Jungle }\end{array}$ & $\begin{array}{l}\text { Soil wall hole and broken } \\
\text { in the wall }\end{array}$ & $\begin{array}{l}\text { Sleep without net and } \\
\text { malnutrition }\end{array}$ \\
\hline Too Much & 30 & 61 & 25 & 47 \\
\hline Much & 31 & 19 & 33 & 33 \\
\hline A little & 29 & 13 & 47 & 25 \\
\hline Very Little & 7 & 6 & 4 & 5 \\
\hline No Comment & 3 & 2 & 1 & 0 \\
\hline
\end{tabular}

Table 4 shows, they claim the lack of space they have for housing has high impact causing black fever. They believe, their housing patterns and material used to make wall and floor are responsible for black fever spread. They also agree that malnutrition and not using net was responsible for expansion of this diseases.

\subsection{Indigenous Diagnosis System and Etiology of Illness}

\subsubsection{People Knowledge About Black Fever}

Most of the people at the first time could not able to recognize it. After having some experience from other, they learn how to recognize black fever. Many people spot it by noticing skin color; which is black. Most of the people recognized it after medical test.

Table 5. Patients first realization about black fever.

\begin{tabular}{ll}
\hline How they understand & Percent (\%) \\
\hline People understand by own self & 4 \\
People known by the other & 26 \\
Known by medical test and NGO & 70 \\
\hline
\end{tabular}

Table 5 shows, only $4 \%$ people recognize a black fever patient as a first place. $70 \%$ people know about the diseases only when they go through medical test.

\subsubsection{People Take Time to Recognize Black Fever}

Only few local people can identify the black fever patients from their primary stage. Most people understand when black fever reaches its last stage. The first stage symptom is normal fever. So people didn't able to recognize black fever. People understand when skin became black or making medical test.

\subsubsection{Belief Related with Supernatural Power}

They belief if the people and community make enough sin, then the community attack by the black fever. It is a curse for them. It kills the entire guilty (Pappy) Person. There is a belief of supernatural power that mean's Jinn and Pori (female Jinn). Escape from these Jinn and Pori the Bon the village specific house or their living room by a Shaman (ogza). They did not keep window because the Jinn and Pori can come through the window and also when a person see a Jinn and Pori through a window he can attack by supernatural power.

Researchers also found, Aristotle Baska Age 55 lives in Rajshahi District. He said that his son and daughter in law attacked by black fever because his son says bad things about Jinn and Pori. In returns, his son and daughter got black fever. His daughter in law got black fever too. Because, she is inflicted by supernatural (Jinn and Pori) power. One night she saw Jinn and Pori, then she attacked by Jinn and she became weak. After closing the house by spelling and taking tabij from shaman (ogza) she becomes cure.

\subsubsection{Some Person Belief That It's Shoasa or Touchable}

Some of the people said that it is touchable (shoasa). They said because it found at a time among the entire village and in a family always more than one-person attack or died by black fever. That's why they make separated plate, glass and bed for black fever attacked person.

That family whose member attacked by black fever other people always kept distance from them. Because they think that it is touchable. People avoid them directly. One of the girls that time was reading in class six and he takes tuition from a person who lives in their village. But after death of the girl's parent and sister the Teacher stop her tuition and said that you didn't need to come. Because the teacher thought that black fever is a killer and it also shosa. Because the girl's father died by black fever and her mother stay with her father in the same room and now the girl's staying with her mother. 
Table 6. Factor affecting on black fever treatment.

\begin{tabular}{lllll}
\hline $\begin{array}{l}\text { Degree of impact on } \\
\text { treatment }\end{array}$ & Causes & & & Belief relation with \\
\cline { 2 - 5 } & $\begin{array}{l}\text { People knowledge about } \\
\text { black fever }\end{array}$ & $\begin{array}{l}\text { People take time to } \\
\text { recognize black fever }\end{array}$ & $\begin{array}{l}\text { person belief that it's } \\
\text { shoasa or touchable }\end{array}$ \\
\hline Too Much & 78 & 74 & 31 & 59 \\
Much & 16 & 16 & 30 & 21 \\
A little & 2 & 9 & 30 & 15 \\
Very Little & 1 & 1 & 4 & 4 \\
No Comment & 3 & 0 & 5 & 1 \\
\hline
\end{tabular}

Respondents agreed upon two issues, which are responsible to hamper getting proper treatment. Almost 3 out of four people said that, lack of knowledge of black fever and late recognition of black fever has major impact on black fever treatment. Black fever is considered as touchable diseases. In terms of responsibility of supernatural power as a reason behind black fever, peoples are confused. Some says it has major role behind black fever, other says, it has less influence on black fever.

\subsection{Side Effects of Treatment}

When a black fever patient using DDT to reduce sand flies, take multi-vaccine from any medical center. They face different kind of side effects. Many patients show no side effect too.

Table 7. Post treatment side-effects.

\begin{tabular}{ll}
\hline Problem & Percent (\%) \\
\hline Reduce of eye sight & 6 \\
Headache & 10 \\
Skin turns into black & 30 \\
Allergic symptom & 6 \\
New spot in skin & 3 \\
No problem & 45 \\
\hline
\end{tabular}

After taking medicine, $45 \%$ patients to faces no problem. But some time they face side effects. Like as, 30\% patients say their skin turns into black, $10 \%$ having headache, $6 \%$ having visioning problem, another $6 \%$ have some allergic problem and $3 \%$ patients found new spot on skin.

\section{Conclusion}

Health seeking behaviors is not just an isolated event. It is result of indigenous Santal people sense and etiology. Health seeking behavior depends on patient perception about disease and also related to the process of identify disease. Santal people cultural practice is responsible for attacked by black fever. Their house hold pattern, poverty and malnutrition make them worse sufferer in disease. People knowledge, belief and time to identity the disease have much influence on treatment. Our Bangladeshi people is not well conscious about their disease etiology, it also influences health seeking behavior of black fever. After identify disease, they percept differently about their disease. When they to take treatment, they always thing about their economic condition, transportation, belief and other. At the End they are taking treatment from medical central. We must think, how people perceive about diseases and etiology, when we are discussing for their health care. Then our people can able to take right health care. The Santal people attacked by black fever for their cultural practice. Their food habit, household condition is the major cause for it. When they attack by black fever at first time they didn't understand. If we make conscious and try to teach people about different kind of disease, our society people feel comfortable about the disease. So by understanding the people sense and etiology of black fever, we can able to provide better treatment on black fever in locally and globally.

\section{References}

[1] WHO, TDR (Tropical Diseases Research) Report, World Health Organization, 2012.

[2] Singh, R. K., H. P. Pandey, and S. Sundar, "Visceral leishmaniasis (kala-azar): challenges ahead". Indian Journal of Medical Research, vol. 123 (3), 2006, pp. 331.

[3] Status of endemicity of visceral leishmaniasis, worldwide, International Centre for Diarrhoeal Disease Research (icddr, b), 2012.

[4] Desjeux, P. "The increase in risk factors for leishmaniasis worldwide", Transactions of the Royal Society of Tropical Medicine and Hygiene, vol. 95 (3), 2001, pp. 239-243.

[5] WHO, TDR (Tropical Diseases Research) Report, World Health Organization, 2012.

[6] Alvar, J., Iván D. V., Bern C., Herrero M., Desjeux P., Cano J., Jannin J. and Boer M., "Leishmaniasis worldwide and global estimates of its incidence", PloS one, vol. 7 (5), 2012, e35671.

[7] WHO, Health Bulletin, World Health Organization, Chapter 9, 2012, pp. 102-104,

[8] Jorge A., Vélez I. D., Bern C., Herrero M., Desjeux P., Cano J., Jannin J., and Boer M., "Leishmaniasis worldwide and global estimates of its incidence", PloS one 7, no. 5, 2012, e35671.

[9] Ahmed, B., Nabi, S. G., Rahman, M., Selim, S., Bashar, A., Rashid, M, Lira, F. Y., Choudhury, T. A., and Mondal, D. "Kala-azar (visceral leishmaniasis) elimination in Bangladesh: successes and challenges". Current Tropical Medicine Reports 1, no. 3, 2014, pp. 163-169.

[10] The daily Sonali Sangbad, July 29, 2004. 
[11] WHO, Second WHO report on NTDs, World Health Organization, Chapter 3.9, 2013, 67-71.

[12] Desjeux, P., "Human leishmaniases: epidemiology and public health aspects". World health statistics quarterly. Rapport trimestriel de statistiques sanitaires mondiales, vol. 45 (2-3), 1991, pp. 267-275.

[13] WHO, Second WHO report on NTDs, World Health Organization, Chapter 3.9, 2013, pp. 67-71.
[14] Bern, C., Allen W. H., Chowdhury R., Ali M., Amann J., Wagatsuma Y, Haque R. et al. "Risk factors for kala-azar in Bangladesh". Risk, 2005.

[15] STATISTICS, B. B. O., "Population and housing census $2011 ", 2012$.

[16] Surendran, S. N., A. Kajatheepan, and R. Ramasamy. "Socioenvironmental factors and sand fly prevalence in Delft Island, Sri Lanka: implications for leishmaniasis vector control." Journal of vector borne diseases, vol. 44 (1), 2007, pp. 65. 